\title{
Modern stratagems for renewing the competitive environment of construction development
}

\author{
Ryzhakov D. A. ${ }^{1}$, Kondratsky V.O. ${ }^{2}$ \\ ${ }^{1} \mathrm{PhD}$, Associate Professor, Building economics department, Ukraine \\ ${ }^{2} \mathrm{PhD}$ student ,Kyiv National University of Construction and Architecture, Kyiv, Ukraine
}

\begin{abstract}
The company can maintain its competitive advantage through two the kinds of abilities - distinctive and replicable - and the unique combination of these that the organization creates to achieve synergy. The determining factor is the importance of the company's strategy. New concepts of competitiveness do not deny the importance traditional factors such as company size, assortment policy, price differentiation and low costs. At the same time, the special importance of new factors - key competencies, brand value, reputation, i.e. resources that are intellectual.
\end{abstract}

Keywords: innovation activity, company competitiveness, operating efficiency, strategy.

\section{Introduction}

Given the leading role of competition as a natural incentive of innovative activities, it is necessary to form a competitive environment - primarily through the support of small and medium sized business, reduction of barriers to market entry for innovative firms. Improvement of the financial infrastructure of innovative and the use of direct financial incentives, tax breaks for high-tech enterprises and those engaged in the development and implementation of innovations, in order to providing firms with greater access to financial resources.

The purpose of the article is to formulate the main directions of creation of institutional support of the innovative development of the firm in a competitive environment based on the analysis of obstacles to innovative development, both from the standpoint of external and internal institutional conditions.

\section{The results}

The most common notion of a company's competitiveness is the ability of the firm (company) to compete in the markets with producers and sellers of similar goods and services by providing higher quality, affordable prices and convenience to buyers and consumers. This definition overlooks such important characteristics as: the potential of the enterprise, the functioning of the company within a certain market, conditions and time, the reduction of competitiveness to the production of competitive goods or services.

In our opinion, competitiveness (in general) is the presence of a company with certain competitive advantages and its ability to use these advantages in competition. Competitiveness has 3 characteristics:

The first is that the company has certain resources.

The second indicates the so-called "operational efficiency" of the company, described by such indicators as: profitability; science intensity; degree of activity differentiation; company's share in the national market and degree of its stability over a certain period of time; price index for products or services.

The third important characteristic is the development of an effective development strategies. It is important to emphasize the importance of the complex use of these conceptual approaches in the formation of modern theory of competitiveness of the market enterprise. Hypertrophied orientation to this or that conceptual approach, without taking into account the multidimensionality, multilevel problems of competitiveness can hardly be justified. This multidimensionality actualizes the development of complex classification of enterprise competitiveness, which can be presented in the following form.

On the basis of influencing factors it is expedient to distinguish: a) exogenous competitiveness of the enterprise, provided mainly due to the action of external factors of the economic policy of the state in relation to the company's management; b) endogenous competitiveness of the enterprise, provided mainly due to the realization of the internal potential, those intra-production factors (machinery, personnel, management, etc.), which on their own basis create competitive advantages of the company; c) system competitiveness of the enterprise 
On the basis of the scale of its manifestation it is necessary to distinguish: a) global competitiveness of the enterprise, which is characterized by international leadership (in the relevant industry); b) national competitiveness of the enterprise, the competitive advantages of which are realized in the scale of a particular country (by industry, type of economic activity); c) regional competitiveness of the enterprise, the competitive advantages of which are realized only on the scale of one or a group of regions (due to certain regional.

On the basis of sustainability, a distinction should be made between: a) the stable competitiveness of the enterprise, which is ensured through the presence of long-term competitive advantages, as well as sustainable mechanisms of reproduction of these advantages; b) unstable competitiveness, which is the result of any short-term, transitory and (or) external factors, which are not dependent on the enterprise itself, and on which the rate from the point of view of ensuring competitiveness is unjustified or highly risky; c) achieved through "overpowered", which is used.

On the basis of realizability it is necessary to distinguish: a) potential competitiveness of the enterprise, which is characterized by the fact that the objective competitive advantages of business are not realized due to certain internal and (or) external reasons; b) actual competitiveness of the enterprise, in which its competitive advantages are stably enough manifested in the real business, are realized in the actual indicators of the main activity of the company.

By type of attribute it is necessary to distinguish: a) product competitiveness of the enterprise, at which the actual output of competitive (mainly due to prices) products is provided, but the quality of resource potential is characterized by lower parameters than those of competitors; b) resource competitiveness of the enterprise, at which the parameters of the resource base of the enterprise correspond to or even exceed the parameters of competing companies, but due to various reasons the competitiveness of products on the market is not provided.

On the basis of progressivity it is expedient to distinguish: a) traditional competitiveness of the enterprise, achieved on the basis of the use of known (not badly proved in the past) factors; b) innovative competitiveness of the enterprise, which is based on scientific and technical (innovative) competitive advantages of the company, its ability to create technological and organizational "know-how", to use advanced achievements of science and technology in the interests of the development of its own business. The proposed author's classification, first of all, expands the theoretical understanding of the conditions of formation and implementation of competitiveness of the enterprise, structural and functional features of this complex economic category. Secondly, it allows the management of companies to identify more clearly the basic state of competitiveness and plan measures to improve it.

In contrast to the traditional approach to the formation of separate functional strategies of the enterprise, the strategy of increasing competitiveness (hereinafter - business or competitive strategy) can be considered as a concept and plan of long-term actions for the use of a set of exogenous and endogenous factors of competitiveness in order to preserve and increase the competitive market advantages of the company. Thus, depending on importance and specificity of a problem for the enterprise, questions of escalating of strategic competitive advantages of the enterprise can be provided both in rather independent perspective business plans on separate spheres of activity (operational, marketing, etc.), and in the special (independent) plan of corresponding actions.

Unlike the traditional approach to the formation of separate functional strategies of the enterprise, the strategy of increase of competitiveness (further - business or competitive strategy) can be considered as a concept and plan of perspective actions on the use of a set of exogenous and endogenous factors of competitiveness in order to preserve and increase competitive market advantages of the company. Thus, depending on importance and specificity of a problem for the enterprise, questions of escalating of strategic competitive advantages of the enterprise can be provided both in rather independent perspective business plans on separate spheres of activity (operational, marketing, etc.), and in the special (independent) plan of corresponding actions.

\section{Conclusions}

Recommended basic sequence of management actions at the stage of identification of the state of competitiveness. Realizing the given algorithm, management should proceed from necessity of reception of a complex and clear picture of competitiveness of business, first of all in the accounting (base) period. Achieving the competitiveness of products is considered as a necessary, but not sufficient condition for ensuring the competitiveness of the enterprise. At a stage of formation of strategy of growth of competitiveness of the enterprise the basic purpose of management is designing of system of the perspective actions providing success in competitive struggle and co-ordinated with resource possibilities of the company. The key questions of organization of perspective planning of measures on increase of competitiveness are a choice of type (kind) of competitive strategy and formats of planning. 


\section{References}

[1] Sorokina, L.V., Goiko, A.F., Stetsenko, S.P., Izmailova, K.V. (2017) Ekonometrychnyy instrumentariy upravlinnya finansovoyu bezpekoyu pidpryyemstv budivnytstva [Econometric tools for financial security management of construction companies], Kyiv. KNUBA. [in Ukrainian].

[2] Marchuk, T.S. (2017) Identification of the basic elements of the innovation-analytical platform for energy efficiency in project financing. Investment management and financial innovations, no.14, 12-20. [in English].

[3] Chernyshev, D., Ivakhnenko, I., Ryzhakova, G. (2018) Implementation of Principles of Biospheric Compatibility in the Practice of Ecological Construction. International Journal of Engineering \& Technology; Vol 7, No 4.8: Special Issue 8, pp. 424-427.

[4] Ryzhakova, Galyna, Malykhina, Oksana, Ryzhakov, Dmytro (2018). Risk-management in the system of management of integration processes as a component of modernization of Ukrainian economy. Management of Development of Complex Systems, 36, $113-119$.

[5] Ryzhakov, Dmytro. (2017). Application of BSC-technologies for formalized mapping of features of subcontractor operations in reengineering projects. Management of Development of Complex Systems, 32, 153-158.

[6] Ryzhakova, Galyna, Prykhodko, Dmitry (2017). Models of target selection of representative indicators of activities of construction enterprises: the etymology and typology of systems of diagnostics. Management of Development of Complex Systems, 32, 159-165.

[7] Pokolenko V.O.and Ryzhakova G. M. Implementation of the toolkit for choosing alternatives for the implementation of construction projects on the functional and technical reliability of implementing organizations Management of the development of complex systems. - 2014. - Vip. 19. - p.104-108

[8] Chuprina, Yuriy. (2018). Problems of development of construction clusters as mechanisms of realization of state investment target programs. Management of Development of Complex Systems, 36, 120 - 125. 